\title{
Project Based Learning and Learning Environments
}

\author{
Frank Kurzel and Michelle Rath \\ University of South Australia, Adelaide, Australia
}

\section{Frank.Kurzel@unisa.edu.au Michell.Rath@unisa.edu.au}

\begin{abstract}
In this paper, we describe the characteristics of Project Based Learning, a derivative of problem based learning and report on a multimedia course where this methodology was pursued. The instructional materials are reported on and the artefacts/documentation developed by students discussed. A factor analysis was performed on questionnaire data that was collected at the end of the semester to evaluate the methodology pursued and the instructional artefacts developed. The results of this analysis are discussed along with the implications of this analysis on the use of online learning environments. A model to provide alternate instruction in an online environment are further discussed.
\end{abstract}

Keywords: Personalised Learning Environment, learning objects, instruction, project based learning, course metadata.

\section{Introduction}

It has been suggested (SCORM 2003) that the uptake of technologies supporting learning objects will depend "on the ability of those technologies to tailor instruction to the needs of individuals". As previously reported (Kurzel 2007), this tailoring can impact on the:

- content that is accessed and the media forms used in its representation

- groupings of the content and the relationships between them

- method of instruction employed and the learning styles supported

- interactions that the student has with tutors and other students

- computer interface that the student interacts with and perhaps modifies.

The instruction employed will play a significant role in this uptake and will certainly be a reflection of the learning theory adopted by the instructor. Instructional models can be placed in two broad categories: instructor-driven and based on cognitive learning theory, or student-driven and

Material published as part of this publication, either on-line or in print, is copyrighted by the Informing Science Institute. Permission to make digital or paper copy of part or all of these works for personal or classroom use is granted without fee provided that the copies are not made or distributed for profit or commercial advantage AND that copies 1) bear this notice in full and 2) give the full citation on the first page. It is permissible to abstract these works so long as credit is given. To copy in all other cases or to republish or to post on a server or to redistribute to lists requires specific permission and payment of a fee. Contact Publisher@InformingScience.org to request redistribution permission. based on constructivist learning theory (Allert et al., 2002). Expository teaching lies in the first category. An instructor, in this case the lecturer, organises learning material into a hierarchical structure, starting with introductory material and building on those ideas using repetition and practise to reinforce principles.

It is the instructor's role to guide the learning, integrating new ideas with 
previously taught ideas. The content knowledge is delivered before a problem is introduced, allowing students to apply that attained knowledge to the problem (Wee, 2004). University teaching has historically been in this format of lectures and tutorials.

On the other hand, the basis of constructivist learning theory is that

'knowledge can be constructed personally, through reflection and relating new knowledge to prior experience, or socially, through interaction and discussion with others, such as teachers, other learners or family and friends. Either way, knowledge becomes personal and embedded within a context that is relevant to the learner's own life and experience' (Bates, 2005, pp. 55-56).

The problem based learning model is an example of a constructivist learning theory. It has traditionally been used to teach medical sciences where a problem is defined, researched and reported on. What about a multimedia course where the final outcome is an interactive game set up as a course-long project? Derry \& Hmelo-Silver (2005) use the term 'case-based problem solving' in their report of their problem based learning model used to teach teachers. Savin-Baden (2003) defines project-based learning as being something different to problem based learning, whereas Boud (1985) claims they can be the same.

In the context of teaching a course based around a multimedia major project, the project becomes a major problem and stages within the the project become smaller problems that are inter-related and need to be satisfied.

Traditionally, problem based learning is based in a classroom. The group meets where an instructor can facilitate the discussion of the learning issues. Individual research may be conducted offcampus but the collaborative learning integral to this methodology is provided by face-to-face communication and the process of negotiation of outstanding learning issues.

Savin-Baden (2003) introduced computer-mediated collaborative problem-based learning as a model that combines the current trend of online-learning within universities, with a problem based learning focused instructional methodology. She argues that if teams of students are provided with asynchronous (real-time) communication tools such as shared whiteboards and chat rooms, 'computer-mediated communication can provide more intense communication than faceto-face teams' (Savin-Baden, 2003, p. 93).

Project Based Learning (PBL) was the instructional methodology pursued in the course 'Interactive design for multimedia' that had a multi-phase project as the major assessment component. A blended delivery mode was used; non compulsory lectures were given and were supplemented with practical sessions that involved support groups. An in-house online delivery system was used for all instructional content (Reid 2007).

\section{Supporting Project Based Learning}

The individual project involved the authentic task of designing and creating a prototype for a multimedia application that provided an interface to the media materials of a local recording artist. These included:

- images from recent concerts

- songs in mp3 format

- lyrics of recorded songs

- video footage

- biographical information

- and artist website 
Early formal sessions presented the project brief, media materials and information on the process, including extra instruction to build upon previous knowledge about the development environment.

In the second half of the semester, lectures were dropped and more emphasis was placed on group driven activities to satisfy the implementation phase of the project. Students had established designs for their projects and had created graphic elements for their respective interfaces. A discussion board was set up to post individual question and answers. Students worked within support groups to establish individual weekly goals; these were reflected on and ammended for the next week. The tutor in these practical sessions, played the role of a facilitator, guiding where required and giving feedback on weekly work and goals pursued.

Allert et al. (2002), specify seven phases within a scenario of problem based learning. Learning objects (LO) used within this methodology should support each of these phases. For example, the goal description maps into the project specification that also contained other criteria to be used. The background knowledge included a revision of the development environment and a formal review of knowledge and skills that would be required.

Table 1: Phases of PBL (Allert et al. 2002)

\begin{tabular}{|l|l|}
\hline PHASE & INSTRUCTIONAL PURPOSE \\
\hline Goal Description & Present problem to be solved. Set ultimate Goal \\
\hline Specify Criteria & $\begin{array}{l}\text { Specify one or more criteria your solution should meet. What } \\
\text { aspects do you want to focus on? How do you know you reached } \\
\text { your goal? }\end{array}$ \\
\hline Background Knowledge & $\begin{array}{l}\text { Identify knowledge needed. Sample and share knowledge. Ask } \\
\text { experts. }\end{array}$ \\
\hline Generate Ideas & Generate ideas. Draft provisional hypothesis. \\
\hline Implement Solution & $\begin{array}{l}\text { Generate and develop solution. Implement. Compare different } \\
\text { solutions }\end{array}$ \\
\hline Reflect & $\begin{array}{l}\text { Evaluate solution, reflect solution, reflect product, reflect proc- } \\
\text { ess. }\end{array}$ \\
\hline Generalize & $\begin{array}{l}\text { Conceptualize, integrate, and generalize your knowledge. Ex- } \\
\text { change from example into theory }\end{array}$ \\
\hline
\end{tabular}

If this methodology were to be delivered soley online, and these phases used as metadata to type learning objects, then the equivalent instructional materials would need to be inplace.

Each learning object, whether a:

- a single piece of content

- a practical to develop some skills

- a group of related tasks

- a problem description

would be used to support a phase in the methodology. In other words, they would play a role in the methodology. This role then might be included in the meta-data for this learning object in the learning environment. In the case of a generic tool like a discussion board used to provide an asynchronous communication for a group, this typing would not make sense. It would be the aretefact instructing on the way to go about it, that would be typed. 
At the end of the semester, a questionnaire was administered to collect voluntary feedback from the students. This consisted of 27 Likert Scale questions that were presented online through an online survey system. Students were also made aware of Learning Style classifications, in particular, Felder's (1993) to introduce the notion.

The goal of this questionnaire was to evaluate the methodology employed and the learning resources that were put into place to support it. Further, students were able to comment on the documentation that they produced throughout the durationof the project. These results then would hopefully give some insight into the instructional materials required and how they would be described by meta-data if they were to be administered and supported in an online learning environment (LE).

\section{Results and Discussion}

A factor analysis was applied to the 27 item scale that came from the questionnaire. It was apparent that a 3 factor resolution, accounting for $45 \%$ of the overall variance was appropriate. The eigenvalue was set at 2.5 to create the three factors. A principal components analysis was the followed up with a factor analysis using an oblimin rotation. The factor loadings are shown in Table 2 .

The first factor deals with the Instructional Methololgy. The rating of how well the instruction suited the way they liked to learn' loaded positively. Providing scope to display skills and 'a personal assessment of achievement' both load positively upon this construct. Working on an authentic project loaded positively along with being able to satisfy the project requirements of an initially challenging project. Having resources available to satisfy the task loaded positively while having a discussion forum with the group only, loaded negatively suggesting that having a discussion forum with the total group would load positively.

Collaborating with a group that students decided on, the setting of weekly goals, and assessing this, loaded factor 2 which can be referred to as Group Work. The use of the discussion board and an online help further loaded this factor. We would expect this because these tools aid group work. Student agreement with Felder's learning style characteristics loaded negatively.

The third factor I have labelled Difficulty. Item 10 which referred to using smaller tasks loaded posively. Item 3 dealing with the the difficulty of the project components loaded this factor positively as you might expect. A good understanding of Director (the development environment) loaded negatively. We could expect that the the reverse of the statement would load positively. 'Providing varying levels of exlpanation to cater for different backgrounds identified' and 'providing a range of media formats' both loaded positively. Both of these features were not evident in the learning environment. Finally, Item 5 which pertained to the suitability of the methodology, loaded negatively. We could expect that reversing this statement to 'Project based Instruction did not suit the way I like to learn' would have loaded positively. 
Table 2: Factor Analysis: Oblimin Rotation Loadings (with Means)

\begin{tabular}{|c|c|c|c|}
\hline ITEM & STATEMENTS & LOADING & MEAN \\
\hline Factor 1 & $\begin{array}{l}\text { Intructional Methodology is OK (eigen } 4.682 \text {, variance } \\
18.729 \% \text { ) }\end{array}$ & & \\
\hline 13 & $\begin{array}{l}\text { The Instructional methodology in this course suited the way I } \\
\text { like to learn }\end{array}$ & .801 & 2.76 \\
\hline 8 & $\begin{array}{l}\text { The instructional methodology provided me with enough scope } \\
\text { to display my skills }\end{array}$ & .723 & 2.667 \\
\hline 1 & I achieved more in this course than I thought I initially would & .715 & 2.89 \\
\hline 9 & I enjoyed working on a project that was authentic & .659 & 2.37 \\
\hline 2 & $\begin{array}{l}\text { I found the course initially challenging but managed to satisfy } \\
\text { the project requirements }\end{array}$ & .646 & 2.66 \\
\hline 6 & $\begin{array}{l}\text { The resources provided allowed me to satisfy the course re- } \\
\text { quirements }\end{array}$ & .595 & 2.63 \\
\hline 17 & $\begin{array}{l}\text { I would have liked to have a discussion forum with only my } \\
\text { group }(\mathrm{R})\end{array}$ & .519 & 3.593 \\
\hline Factor 2 & Group work (eigen 3.992 , variance $15.969 \%$ ) & & \\
\hline 15 & Working with a group that we decided on was very helpful & .941 & 3.296 \\
\hline 18 & $\begin{array}{l}\text { I found being able to collaborate in my group in practical ses- } \\
\text { sions very helpful }\end{array}$ & .887 & 3.074 \\
\hline 26 & $\begin{array}{l}\text { The component within the assessment to measure participation } \\
\text { within the group was fair }\end{array}$ & .557 & 2.769 \\
\hline 12 & $\begin{array}{l}\text { Did you agree with Felders classification of your Learning } \\
\text { style? (R) }\end{array}$ & .512 & 2.56 \\
\hline 16 & $\begin{array}{l}\text { The setting of weekly goals helped me focus on what needed to } \\
\text { be achieved }\end{array}$ & .501 & 3.111 \\
\hline 23 & $\begin{array}{l}\text { Learning environments can attempt to personalise the content } \\
\text { they deliver with annotations that are visual clues that indicate } \\
\text { whether or not you know the content. These annotations would } \\
\text { assist my learning. }\end{array}$ & .474 & 2.615 \\
\hline 25 & $\begin{array}{l}\text { I found the ability to post questions and read other posting about } \\
\text { the course very useful }\end{array}$ & .461 & 2 \\
\hline 21 & $\begin{array}{l}\text { An online helpdesk for Director would have been very helpful } \\
\text { when working with Director }\end{array}$ & .438 & 2.308 \\
\hline Factor 3 & Difficult (eigen 2.495 , variance $9.981 \%$ ) & & \\
\hline 10 & $\begin{array}{l}\text { I would have preferred the course to be based around smaller } \\
\text { tasks }\end{array}$ & .710 & 2.778 \\
\hline 3 & I found the project components difficult to come to terms with & .667 & 2.63 \\
\hline 7 & $\begin{array}{l}\text { I have a good understanding of how to use Director to produce a } \\
\text { game (R) }\end{array}$ & .640 & 2.462 \\
\hline 27 & $\begin{array}{l}\text { When viewing content about Director, providing varying levels } \\
\text { of explanation to cater for different backgrounds would have } \\
\text { been useful }\end{array}$ & .610 & 1.89 \\
\hline 14 & $\begin{array}{l}\text { The instructional materials need to be in a range of media for- } \\
\text { mats to suit my learning style }\end{array}$ & .561 & 2.6 \\
\hline 5 & $\begin{array}{l}\text { The Project Based Instruction in this course suited the way I like } \\
\text { to learn }(\mathrm{R})\end{array}$ & .479 & 2.778 \\
\hline 4 & I would have preferred to choose my own project & .341 & 2.926 \\
\hline
\end{tabular}

Notes:

(a) The response options were scored 1 to 5. These mapped into: strongly agree/ agree/ neutral/ disagree/ strongly disagree. 
(b) Items scored in reverse (loaded negatively) are shown by (R).

(c) $\mathrm{n}=27$

\section{Implications for Learning Environments}

On examination of the questionnaire data discussed above, the factors that require more consideration are:

- instructional methodology,

- group work,

- difficulty encountered.

An analysis of the means of the items discussed, indicate that their was an overall agreement on the instructional methodology but interestingly, the same could not be said of group work. It appears that it suited some but not everyone. The means of items identified in factor 3 indicate general agreement with the notions expressed.

We could argue that any learning environment delivering courseware in an Information Technolgy related area, needs to be able to tailor the methodology to the individual. In an online environment, this means packaging the content and learning activities in different ways. This packaging and future delivery requires meta-data to automate this delivery. Typically, some Learning Management System (LMS) would perform this in a way that would reflect the instructional model.

Who or what decides on instructional model? Does the LMS use the profiling data it has collected, has access to, or both, to automate this?. We would argue that the student should be able to decide on the particular instructional format and that the system should be scrutable. It could of course be the instructor who decides this. The LMS through some adaptive technique might be able to suggest an appropriate way of going about it. It might also be able to provide alternate content depending the competence profile it has established, or indeed different media formats of LOs depending of student preferences. These notions are closely linked to research of adaptive LMSs based on learning styles (Mustaro, 2006).

We have dicussed expository Learning and project based instruction as two possible ways of presenting coursework on-line. Prevous work (Kurzel, 2007) has presented a model (Figure 1) and an architecture that would enable the tailoring of the instruction to a user. The model depicts the instructional model as a multi-tiered hierarchical directed graph that enables the re-use of objects where appropriate.

In this model, the LMS delivers objects, referred to in the figure as instructional objects, that aggregate either declarative of practical concepts/objects for an instructional purpose, e.g. a practical session. The term concept comes from its use within adaptive hypermedia learning environments (Brusilovsky, 2000). Other instructional objects may be closely aligned to the task at hand; for example, one might describe different techniques used to generate ideas, or indeed to represent designs for solutions. Notice also that links between items represent order; some objects have pre-requisite objects.

Other objects might refer to other tools in the LE; generic items like search engines, indexes, glossaries, discussion boards, chat facilities etc. could actively engage the student, providing tools for the construction of new student knowledge, and communication structures that enable collaborative work on non-trivial projects. 


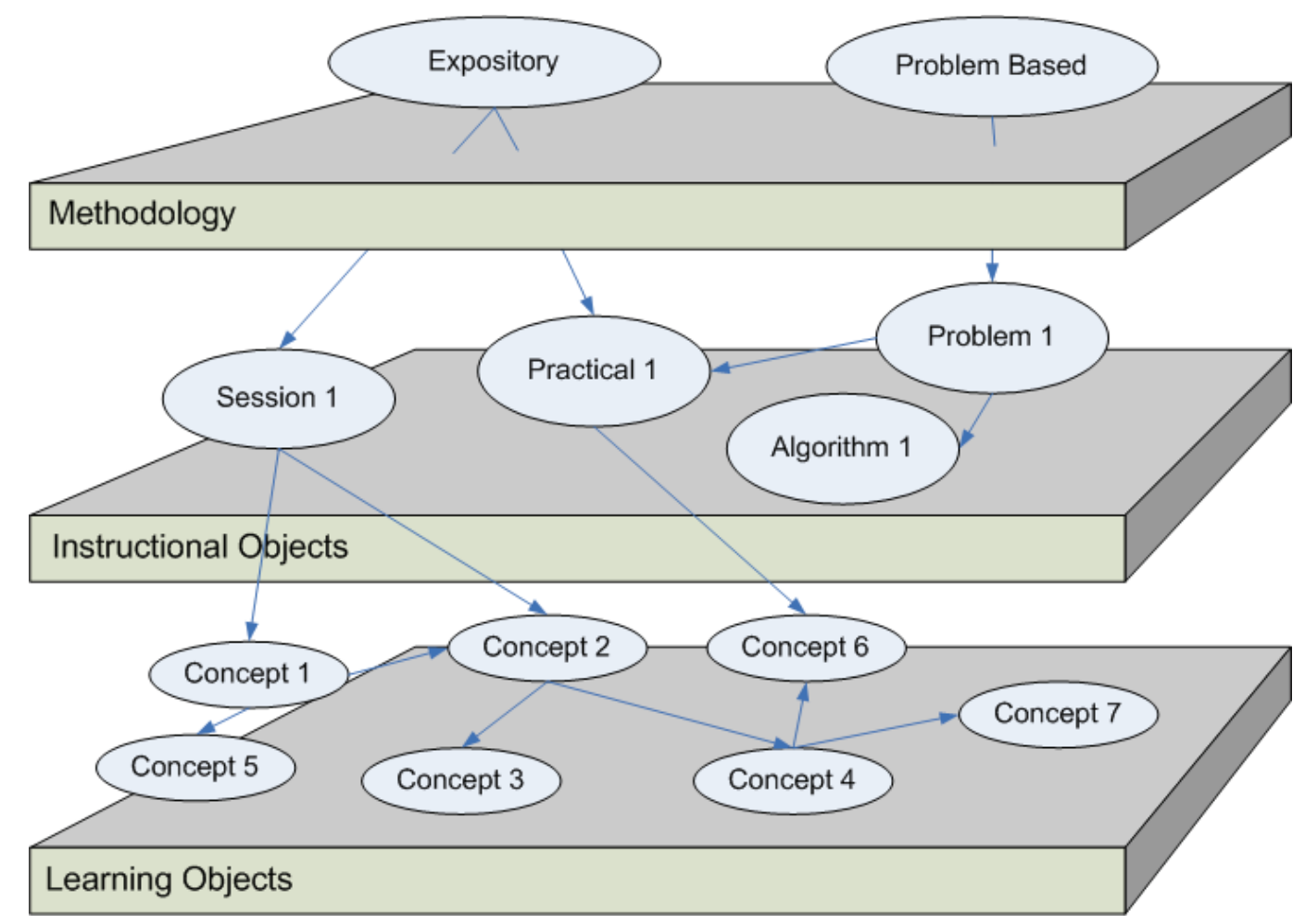

Figure 1: Generalisation of learning Objects (Kurzel, 2007)

\section{Conclusion}

We have conducted an evaluation of an instructional sequence that we have referred to as Project Based Learning, a methodology with similarities to problem based learning. An examination of the means from questionnaires was not very illuminating. A factor analysis identified 3 factors that need further investigaton. Areas of interest included the method of instruction, working in groups and the difficulty of the project.

We would argue that alternate instructional methodologies need to be embedded in the LE to tailor the instruction to the individual. Meta-data based on the roles particular instructional objects play within the methodology of choice are required for automation purposes. A range of other tools like search engines, indexes, help, tutorial groupings etc. support the instruction.

The instructional methodology should be tailored to the individual but the system should be scrutable; that is, the learner should be aware of the profiling and be able to override the system.

\section{References}

Allert, H., Dhraief, H. \& Nejdl, W. (2002). Meta-level category 'role' in metadata standards for learning: instructional roles and instructional qualities of learning objects, COSIGN 2002 - The 2nd International Conference on Computational Semiotics for Games and New Media. Retrieved 5 May 2003, from $<$ http://www.cosignconference.org/cosign2002/papers/Allert.pdf $>$

Baptiste, S. (2003). Problem-based learning: A self-directed journey. NJ, USA: SLACK Incorporated.

Bates, A.W. (Tony). (2005). Technology, e-learning, and distance education ( $2^{\text {nd }}$ ed.). Abingdon, Oxon: Routledge. 
Bereiter, C. \& Scardamalia, M. (2000). Process and product in PBL research. In D. Evensen \& C. Hmelo (Eds.), Problem-based learning: A research perspective on learning interactions. NJ, USA: Lawrence Erlbaum Associates.

Boud, D. (Ed.). (1985). Problem-based learning in education for the professions. Sydney: HERDSA.

Derry, S. \& Hmelo-Silver, C. (2005). Reconceptualizing teacher education: Supporting case-based instructional problem solving on the World Wide Web. In L. PytlikZillig, M. Bodvarsson, \& R. Bruning (Eds.), Technology-based education : Bringing researchers and practitioners together (pp. 21-38). Greenwich, CT: Information Age Publishing.

Brusilovsky, P. (2000). Adaptive hypermedia: From intelligent tutoring systems to web-based education. Intelligent Tutoring Systems, Montreal, Canada: Springer-Verlag.

Duch, B., Groh, S. \& Allen, D. (Eds.). (2001). The power of problem-based learning: A practical "How To" for teaching undergraduate courses in any discipline. Virginia: Stylus Publishing.

Felder, R. (1993). Reaching the second tier: Learning and teaching in college science education. J. College Science Teaching, 23(5), 286-290.

IEEE. (2002). Standard for learning object metadata (1484.121-2002). Retrieved 5 May 2003 from, $<$ http://ieeexplore.ieee.org.ezlibproxy.levels.unisa.edu.au/iel5/8032/22180/01032843.pdf?isNumber=2 2180\&prod=STD\&arnumber $=1032843 \&$ arSt $=+\mathrm{i} \&$ ared $=+32 \&$ arAuthor $>$

Kurzel, F. (2007). A model to support alternate instruction within learning environments delivering learning objects. In A. Koohang \& K. Harman (Eds.), Learning objects: Applications, implications \& fuature directions. Santa Rosa, California: Informing Science Press.

Mustaro, P. \& Silveira (2006). Learning objects: Adaptive retrieval through learning styles. Interdisciplinary Journal of Knowledge and Learning Objects, 2, 35-46. Retrieved from http://ijklo.org/Volume2/v2p035-046Mustaro.pdf

Savin-Baden, M. (2003). Facilitating problem-based learning: Illuminating perspectives. Berkshire, England: SRHE and Open University Press.

Reid, I. (2007). Embedding instructional design with learning objects. In A. Koohang \& K. Harman (Eds.), Learning objects and instructional design. Santa Rosa, California: Informing Science Press.

SCORM. (2003). Sharable content object reference model (SCORM) 1.2.

Wee Keng Neo, L. (2004). Jump start authentic problem-based learning. Singapore: Pearson Education South Asia

\section{Biographies}

Frank Kurzel is a lecturer in the School of Communication, Information and New Media of the University of South Australia. He has been the Program Director for the Multimedia Studies Major within the Bachelor of Arts program at the University of South Australia. He has had extensive experience in Education, Computer Science and Multimedia areas. His research interests include web-based instructional systems to support his teaching, and the integration of Intelligent Tutoring Systems technology into hypermedia environments. He is also interested in instructional methodologies and enhancing the educational environment.

Michelle Rath has recently graduated from the University of South Australia with a degree in Computing and Multimedia. She has worked as a tutor for a number of years in the tertiary sector and has developed a wide range of instructional materials to support her teaching. She also has industry experience in database technologies, and the application of these within web-based, multimedia environments. She is currently working as a programmer with a web developer specialisning in dynamic websites. 